\title{
Penambahan Fitur Tampilan LCD dan Micro SD Card Reader pada mesin Laser Engraver and Cutter di Laboratorium Pengemudian Listrik
}

\author{
Mochammad Darwis ${ }^{a}$ \\ ${ }^{a}$ Program Studi Elektro Industri, Polteknik Elektronika Negeri Surabaya \\ Corresponding Author E-mail : mdarwis@staff.pens.ac.id \\ Received: $14^{\text {nd }}$ January 2020; Revised: $18^{\text {th }}$ January 2020; Accepted: $19^{\text {th }}$ January 2020; \\ Available online: $24^{\text {th }}$ January 2020; Published regularly: January 2020
}

\begin{abstract}
Laser engraver and cutter machine that have been made in previous research, can only be controlled by a computer. The addition of LCD display and Card Reader will make it work alone without using a computer (offline). Card reader is used to read gcode files from 2-dimensional design that have been made on a computer. LCD display is used to display a menu or a list of existing settings, the percentage of loading data from a gcode file and displays the 2-dimensional design of the gcode file. To move the menu on the LCD display an encoder switch is used. This additional feature was created using a microcontroller STM32F1 type as a core control system which performs serial communication with a laser machine. 32 bit ARM microcontroller is used because a lot of tasks has to perform. It must be able to read data from the SD card, display the image form from the gcode file and send it to the laser machine. Compared 3 types of gcode file of different file sizes and the speed of loading the data. The laser machine can perform its function by using the controls of the additional feature modules that have been made.
\end{abstract}

Key Words : 32 bit microcontroller, ARM, STM32F1, Card Reader, Encoder Switch, Serial Communication

\begin{abstract}
Abstrak
Mesin laser engraver dan cutter yang sudah dibuat pada penelitian sebelumnya, hanya dapat dikendalikan oleh sebuah komputer. Namun, komputer yang dimiliki jumlahnya terbatas dan harus digunakan untuk keperluan yang lain. Penambahan fitur tampilan LCD dan Card Reader akan membuat mesin laser dapat bekerja sendiri tanpa menggunakan komputer (offline). Card reader digunakan untuk membaca file gcode dari desain 2 dimensi yang sudah dibuat pada sebuah komputer. Tampilan LCD digunakan untuk menampilkan menu atau daftar dari pengaturan yang ada, persentase loading data dari file gcode yang sudah diletakkan pada mikro sd card, dan menampilkan bentuk disain 2 dimensi dari file gcode tersebut. Untuk menggerakkan menu pada tampilan LCD digunakan saklar encoder. Fitur tambahan ini dibuat dengan menggunakan mikrokontroller jenis STM $32 F 1$ yang melakukan komunikasi serial dengan mesin laser. Digunakan mikrokontroller jenis ARM 32 bit karena harus dapat membaca data dari sd card, menampilkan bentuk gambar dari file gcode dan mengirimnya ke mesin laser. Dibandingkan kecepatan loading dari 3 buah file gcode dengan ukuran yang berbeda dan diamti kecepatan loading datanya. Mesin laser dapat melakukan fungsinya dengan menggunakan kendali dari modul fitur tambahan yang sudah dibuat.
\end{abstract}

Kata Kunci : 32 bit mikrokontroller, ARM, STM32F1, Card Reader, Saklar Encoder, Komunikasi Serial 


\section{PENDAHULUAN}

Kebutuhan sebuah komputer oleh seorang PLP adalah sebuah keharusan dalam melakukan tugasnya. Pada penelitian sebelumnya sudah dibuat mesin laser engraver dan cutter untuk membuat casing acrylic yang terhubung dengan sebuah komputer. Jika pada saat yang bersamaan dibutuhkan sebuah komputer untuk melakukan kerja paralel, dan jika hanya sebuah komputer yang dimiliki, tentu hal ini akan menjadi masalah. Dan untuk pengerjaan bentuk yang sama dan dalam jumlah yang banyak, tentunya diperlukan mesin laser engraver dan cutter yang dapat bekerja mandiri tanpa harus terhubung dengan sebuah komputer. Penelitian kali ini akan memberi solusi terhadap masalah yang ada dengan menambahkan fitur tampilan LCD dan pembaca memori SD Card
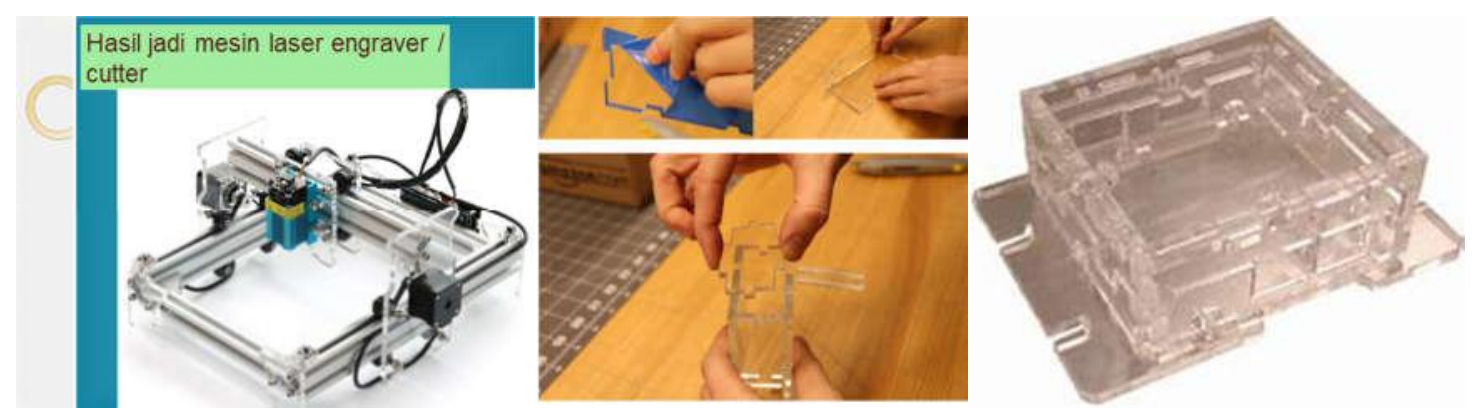

Gambar 1. Mesin Laser Engraver dan Cutter yang sudah dibuat pada penelitian sebelumnya

Yang menjadi permasalahan utama dalam perancangan dan pembuatan prototype ini adalah:

Bagaimana perancangan desain purwarupa (prototype) fitur tambahan pada mesin laser engraver dan cutter, Bagaimana sistem penyimpanan dapat diakses datanya oleh mikrokontroler utama dan ditampilkan disain gambarnya di tampilan LCD dan bagaimana keefektifan dan keefisiensian dari penambahan fitur tersebut

Secara garis besar, tujuan dari pembuatan prototype ini ialah :

Mendapatkan sebuah alat hasil teknologi yang membantu kerja PLP, mahasiswa dan dosen, Dapat menciptakan produk tepat guna dan mendapatkan sebuah alat yang dapat membuat sebuah casing yang dapat didisain dengan komputer dan dapat dibuat dalam jumlah sedikit atau banyak secara mandiri tanpa menggunakan komputer.

Luaran yang diharapkan dari pembuatan alat ini ialah

Mendapatkan sebuah alat yang nantinya bisa membantu dosen, plp dan mahasiswa dalam merancang dan membuat casing akrilik dari sebuah rangkaian elektronik, mendapatkan sebuah alat yang nantinya bisa membantu membuat peralatan untuk mendukung kinerja laboratorium dan mengadakan pelatihan ke sesama PLP agar dapat membuat suatu rancangan benda dengan mesin laser cutte.

\section{BAHAN DAN METODE}

Komponen - komponen elektronik yang digunakan dalam penelitian ini untuk menunjang pembuatan alat dalam penelitian ini, antara lain:

a. Modul Mikrokontroller STM32

Dibutuhkan sebuah mikrokontroller tambahan lagi untuk penambahan fitur terhadap mesin laser engraver dan laser yang ada. Menggunakan mikrokontroller jenis ARM STM32F1. Fitur tambahan akan menggantikan tugas komputer atau PC. Sehingga mikrokontroller pada fitur tambahan ini akan melakukan komunikasi serial dengan mesin laser. Digunakan mikrokontroller jenis ARM 32 bit karena mikrokontroller harus dapat membaca data dari sd card, menampilkan bentuk gambar dari file gcode dan mengirimnya ke mesin laser. Mikrokontroller akan melakukan multitasking dan harus cepat prosesnya. 


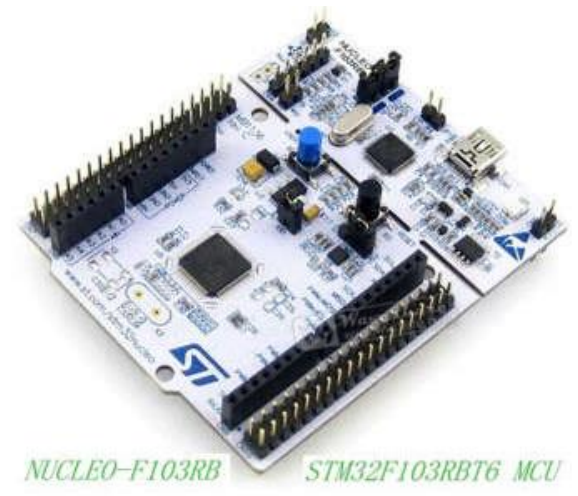

Gambar 2. Modul mikrokontroler STM32

\section{b. Rotary Encoder}

Digunakan rotary encoder untuk melakukan tugas pemilihan menu pada display LCD dengan mudah. Meskipun dapat menggunakan sistem touch screen pada display LCD yang terbaru, namun penggunaan rotary encoder lebih sederhana baik dalam jumlah penggunaan pin input output pada mikrokontroller, maupun kesederhanaan dalam pembuatan perangkat lunak untuk pengoperasiannya

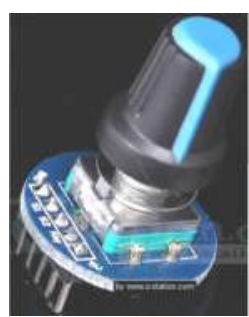

(a)

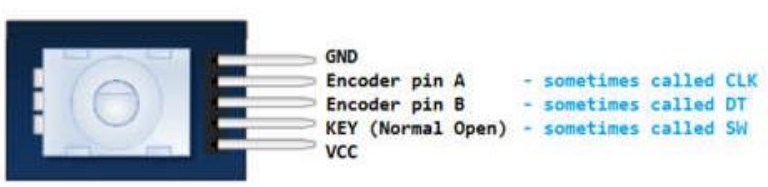

(b)

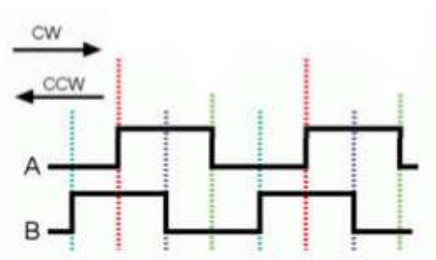

(c)

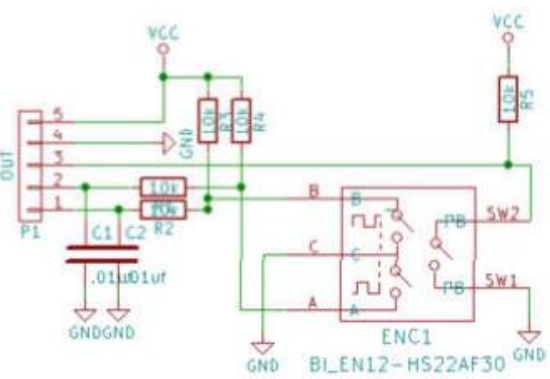

(d)

Gambar 3. Rotary Encoder (a) bentuk fisik (b) pinout

(c) gambar sinyal keluaran pada pinoutnya

c. LCD TFT

(d) skematik antarmuka rotary encoder dengan mikrokontrolller

Tampilan LCD TFT (Liquid Crystal Display Thin Film transistor) digunakan sebagai pengganti monitor di komputer atau PC. LCD akan menampilkan menu pilihan kerja mesin laser engraver atau cutter, gambar disain dari file yang sedang diproses dan status pengerjaan laser yang sedang berlangsung. Dalam penelitian ini digunakan LCD TFT berukuran 3.5 inch 


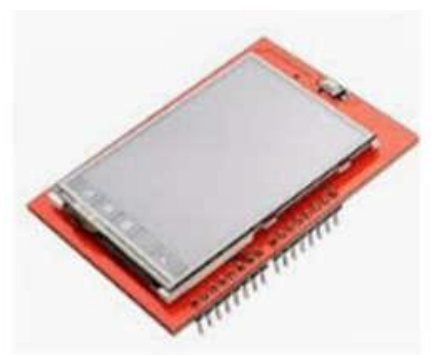

Gambar 4. LCD TFT

\section{d. SD Card Reader}

Modul SD Card reader yang ada dipasaran didisain menggunakan antar muka SPI (Serial Peripheral Interface). File gambar yang sudah didisain di komputer dan sudah dirubah menjadi format gcode (*.NC) akan disimpan pada sebuah SD Card. Modul ini akan membantu mikrokontroller untuk membaca sebuah file gcode yang tersimpan pada SD Card dan menerjemahkannya menjadi gerakan motor stepper pada sumbu $\mathrm{x}, \mathrm{y}$ dan on/off laser

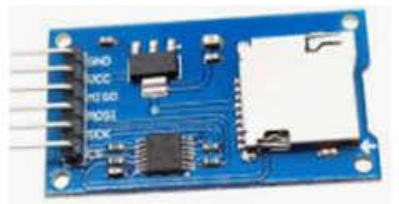

Gambar 5. SD Card Reader

Setelah mendaftar semua komponen elektronik yang diperlukan, maka langkah selanjutnya adalah membuat blok diagram dari sistem yang akan dibuat. Dengan blok diagram ini, perancang sistem dan orang lain yang akan menggunakan sistem, dapat memahami sistem dan cara kerjanya dengan mudah. Blok Diagram dapat dilihat pada gambar 2.5. Disisi kiri gambar adalah modul yang sudah dibuat pada penelitian sebelumnya dan sebelah kanan adalah penambahan fitur yang dibuat pada penelitian saat ini.

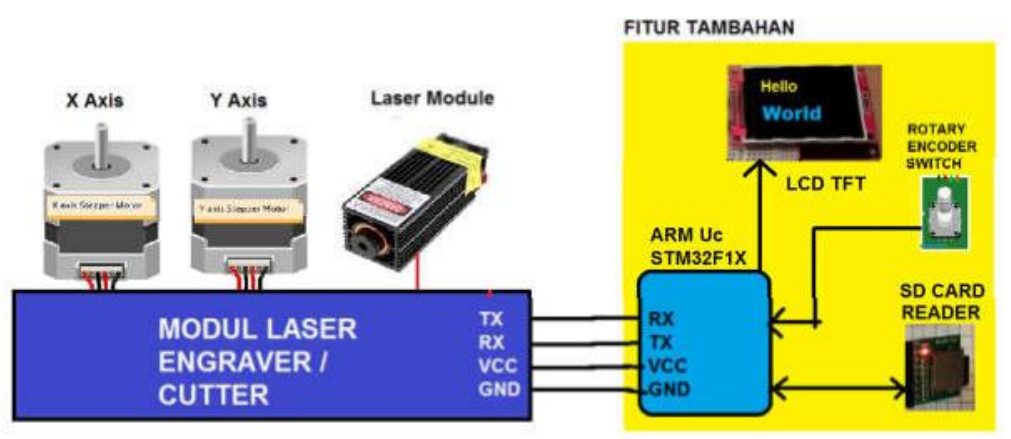

Gambar 6. Blok Diagram Rangkaian

Pada gambar 7 dapat kita lihat proses modifikasi papan kendali utama mesin laser engraver atau cutter. Pada sisi kiri adalah modul kendali utama yang sudah dibuat pada penelitian sebelunya (berwarna hijau) dan pada sisi kanan adalah hasil modifikasi modul kendali utamanya. Perubahan yang mendasar adalah 
ditambahkannya kapasitor pada jalur catu dayanya dan konektor untuk ke modul fitur tambahannya.

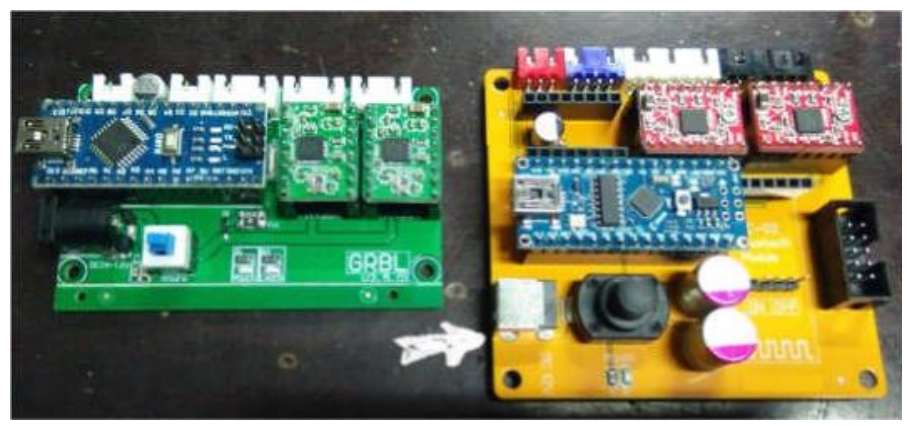

Gambar 7. Disain ulang modul kendali utama mesin laser engraver dan cutter

Konfigurasi pinout pada modul kendali utama, dapat dilihat pada gambar 2.7. Dapat kita lihat bahwa hanya 4 pin yang kita gunakan dari 10 pin yang ada. Dua pin untuk jalur komunikasi serial $(\mathrm{Tx}=$ pemancar dan $\mathrm{RX}=$ penerima) dan dua pin untuk sumber tegangan (Vec dan GND). Pin yang lain yang belum dipakai, dapat digunakan untuk pengembangan di masa yang akan datang.
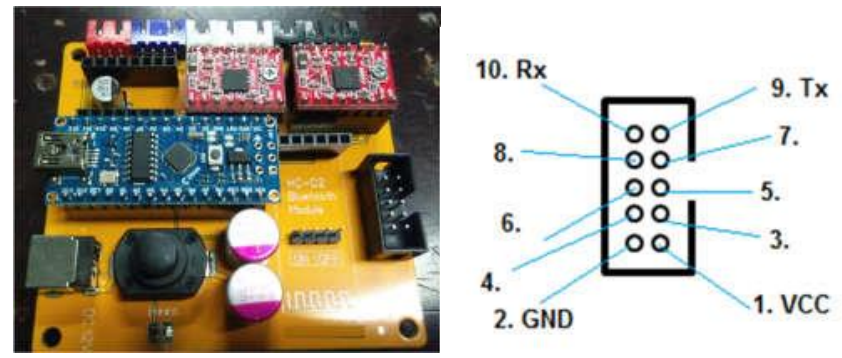

Gambar 8. Konfigurasi konektor untuk penambahan fitur LCD dan Card Reader

Setelah melakukan modifikasi terhadap modul kendali utama, langkah selanjutnya adalah melakukan pengujian terhadap komponen-komponen penyusun modul fitur tambahan. Pengujian pertama adalah pengujian pemrograman sederhana terhadap mikrokontroller yang akan digunakan. Biasanya dilakukan tes uji input output sederhana menggunkan LED dan push button. Kemudian dilakukan pengujian LCD seperti pada gambar 9.

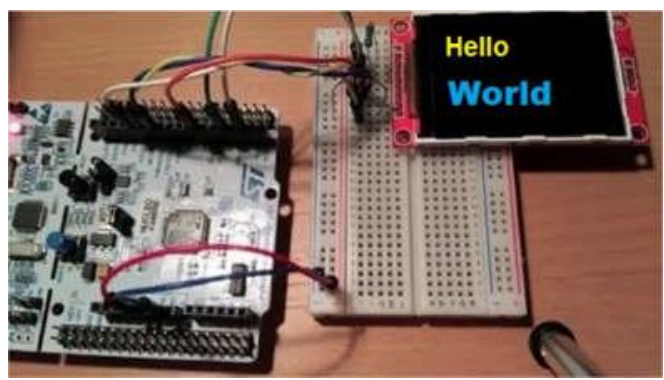

Gambar 9. Tes LCD TFT 
Jika pengujian LCD sudah selesai, maka langkah selanjutnya adalah pengujian rotary encoder (gambar 10.). Jika operasi dasar rotary encoder sudah berjalan dengan baik, maka dapat dibuat pengujian pemilihan menu yang ditampilan di LCD.



Gambar 10. Tes Rotary Encorder

Pengujian selanjutnya adalah uji modul SD Card Reader (gambar 11.). Uji pertama adalah untuk menampilkan daftar nama file yang berada dalam SD Card yang sebelumnya sudah diisi file jenis gcode dari sebuah komputer. Kemudian, akan ditampilkan visualisasi disain gcodenya pada display LCD.

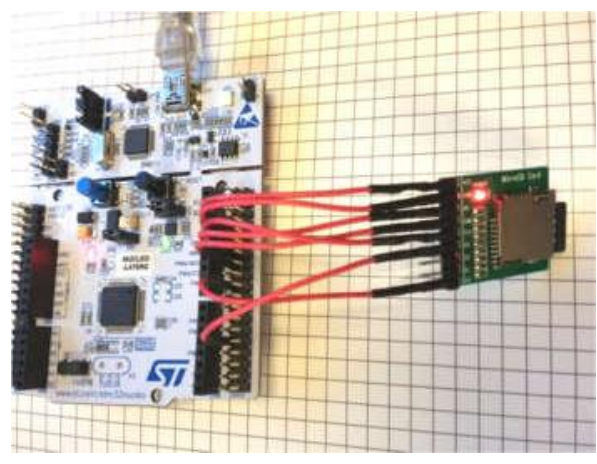

Gambar 11. Tes SD Card Reader

Pengujian terakhir seblum uji integrasi atau penggabungan semua komponen fitur tambahan adalah uji komunikasi serial RS232. Fitur modul tambahan harus berfungsi seperti komputer (karena memang tugasnya menggantikan komputer untuk dapat bekerja mandiri). Menerjemahkan file gcode untuk kemudian memerintahkan modul kendali utama menggerakkan sumbu sumbu x,y dan on/off laser 


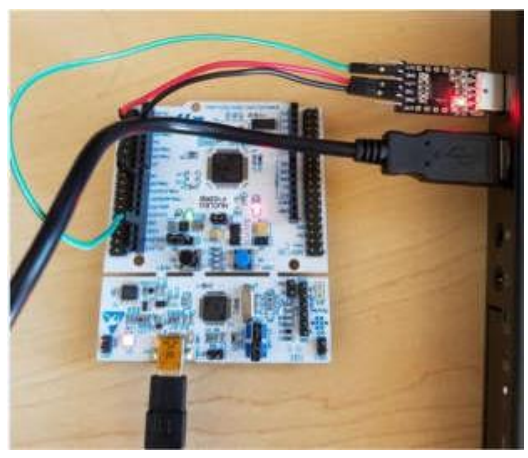

Gambar 12. Tes Komunikasi Serial

Setelah uji semua komponen elektronik penyusun modul fitur tambahan sudah dilakukan, maka langkah selanjutnya adalah mengintegrasikannya dalam sebuah PCB tunggal seperti gambar 2.12.

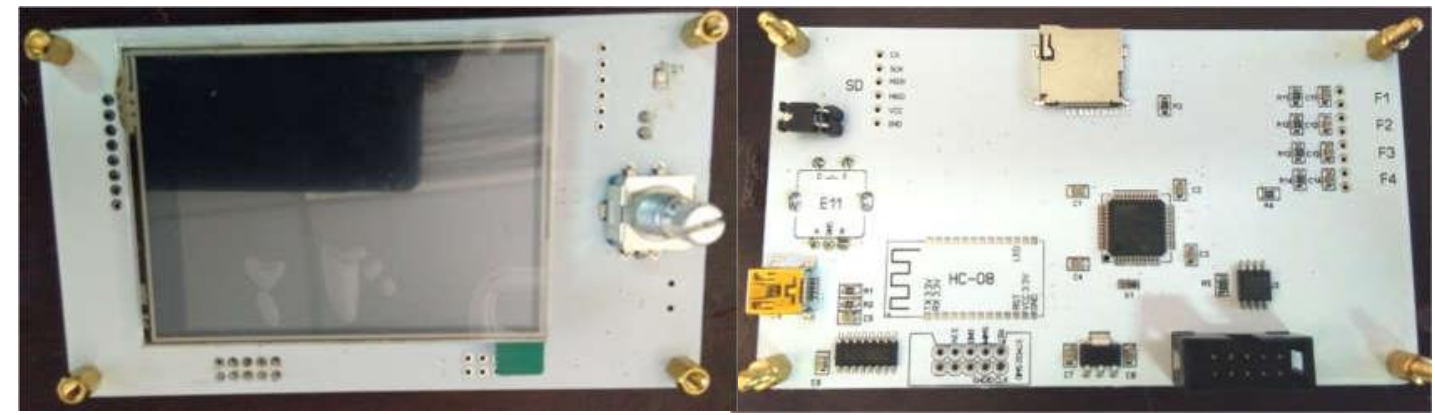

Gambar 13. Modul fitur tambahan pada mesin laser engraver dan cutter

Pengujian paling akhir adalah uji keberhasilan komunikasi antara modul fitur tambahan dengan modul kendali utama seperti pada gambar 14 .

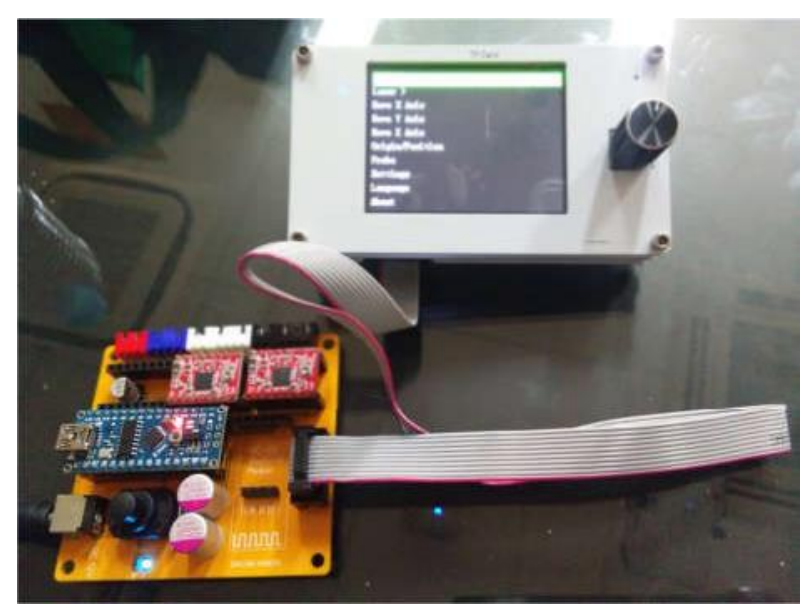

Gambar 14. Rangkaian lengkap modul kendali utama dan modul fitur tambahan

HASIL DAN PEMBAHASAN 
Dibuat tampilan menu yang berisi pemilihan file, penggerakan lengan sumbu mesin secara manual seperti pada gambar 15 . Pemilihan menu menggunakan rotary encoder.
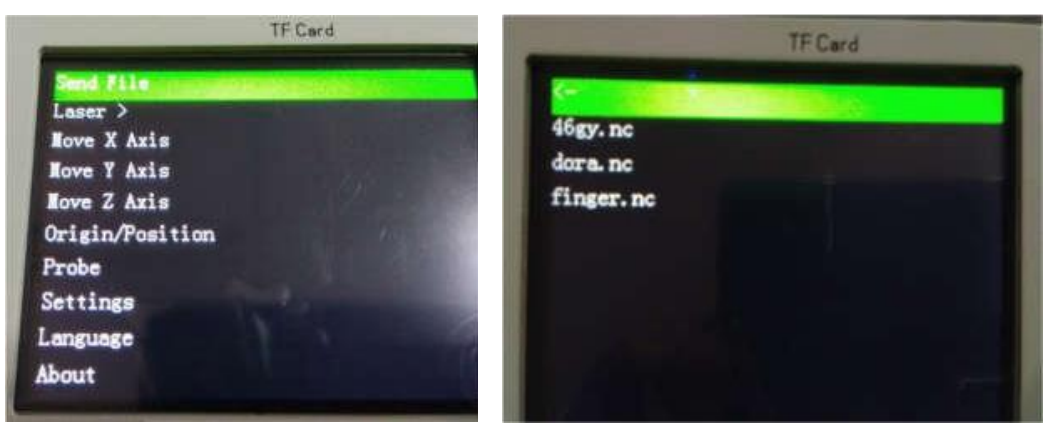

Gambar 15. Sistem Menu yang dibuat

Sebagai uji unjuk kerja modul fitur tambahan, digunakan 3 (tiga) file gcode sebagai pembanding. File yang digunakan dibedakan dari tingkat kerumitan gambar yang dikerjakan. Semakin rumit gambar, semakin besar ukuran filenya dan semakin lama proses pengerjaannya (gambar 16.).
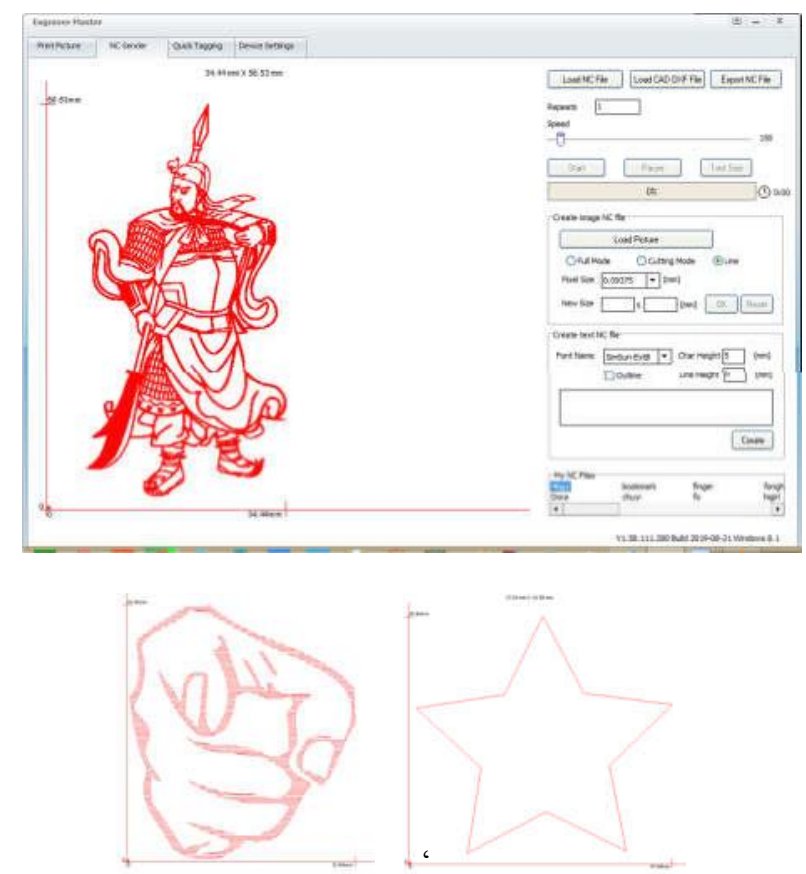

Gambar 16. Contoh bentuk gambar yang akan diujikan

Tabel 1. Ukuran objek Gambar

\begin{tabular}{ccc}
\hline Nama File & Tinggi $(\mathbf{m m})$ & Lebar $(\mathbf{m m})$ \\
\hline 46gy.nc & 58.53 & 34.44 \\
dora.nc & 15.99 & 17.04 \\
finger.nc & 14.15 & 12.64 \\
\hline
\end{tabular}




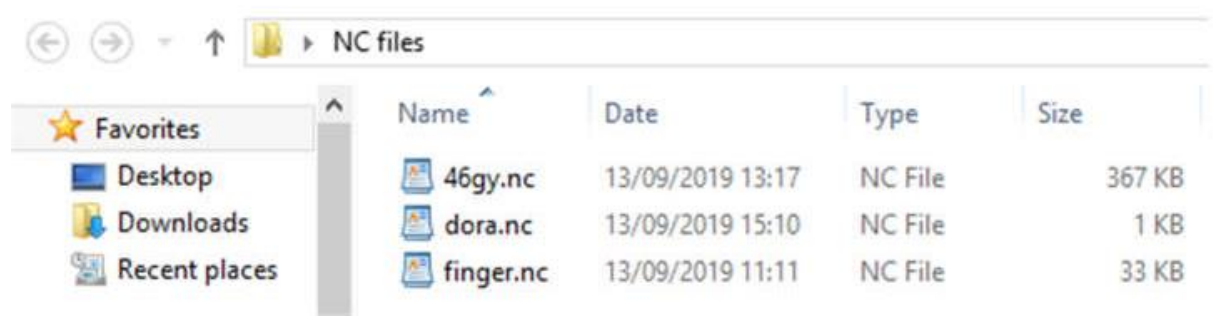

Gambar 17. Ukuran tiap file yang diujikan

Tabel 1. menunjukkan ukuran dimensi tiap gambar yang akan diuji dan gambar 17. menunjukkan besar ukuran tiap file gambar yang akan diuji



Gambar 18. Tampilan display LCD TFT pada tiap file uji
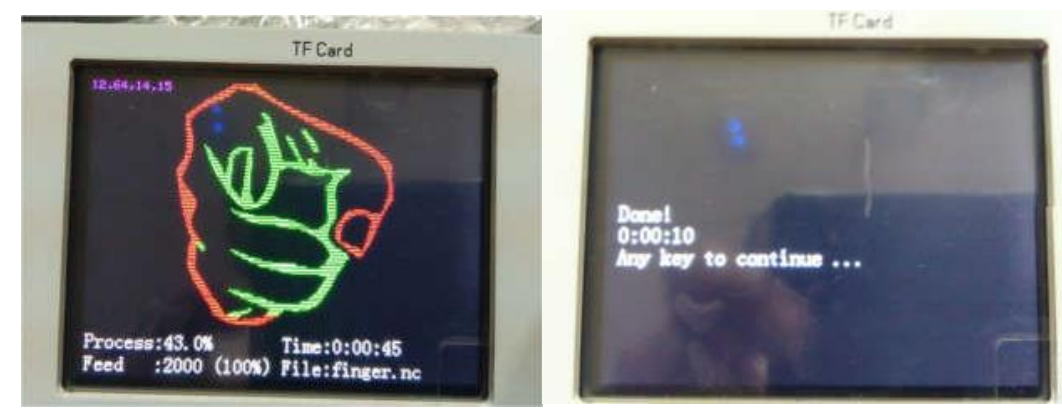

Gambar 19. Tampilan display LCD pada waktu proses sedang berlangsung

Tabel 2. Waktu pengerjaan laser, dengan speed 100

\begin{tabular}{cc}
\hline Nama File & waktu (menit.detik) \\
\hline 46gy.nc & 07.36 \\
dora.nc & 00.10 \\
finger.nc & 00.51 \\
\hline
\end{tabular}

Proses pengerjaan laser engraver dan cutter dengan menggunakan modul fitur tambahan diperlihatkan secara tampilan pada gambar 18. dan 19. Waktu proses pengerjaan laser dengan kecepatan 100 titik perdetik tercantum pada tabel 2. 

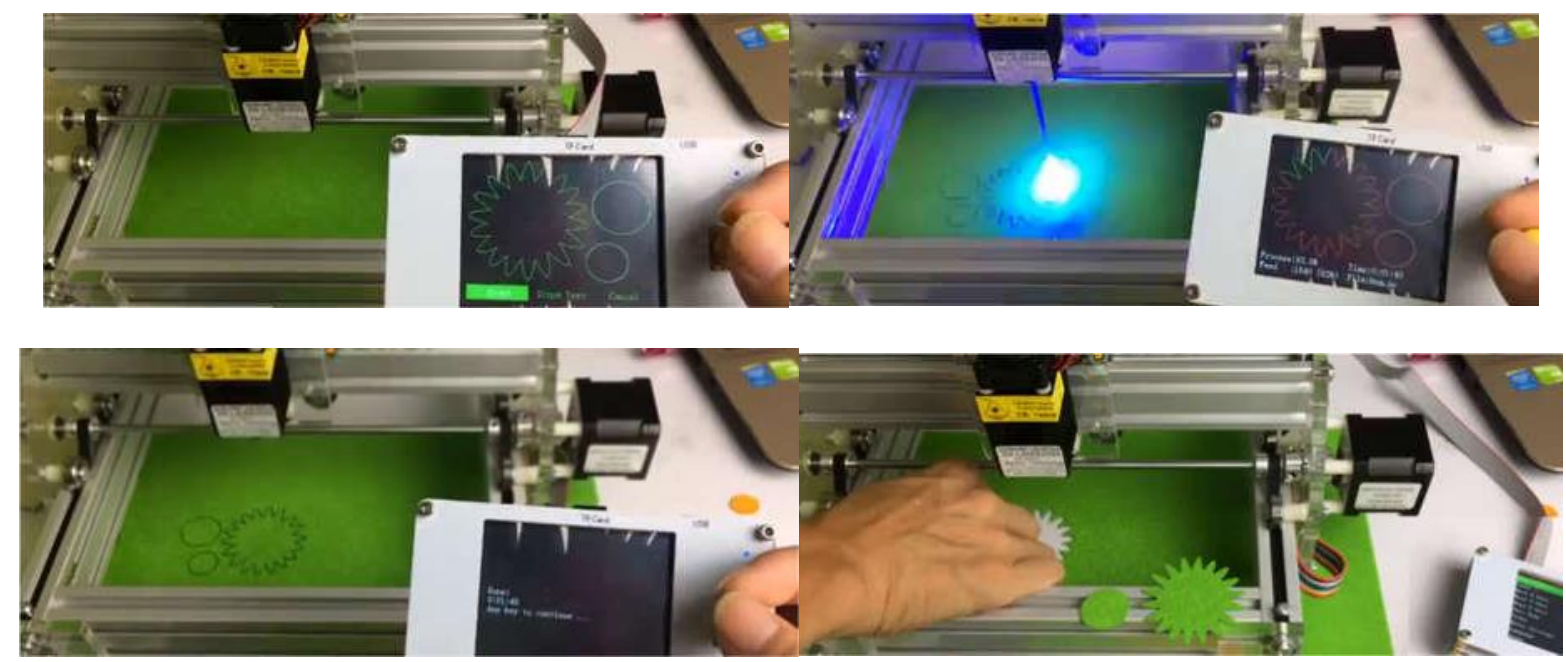

Gambar 20. Proses penggunaan alat laser engraver dan atau cutter dengan Penambahan fitur display LCD TFT dan SD Card

\section{KESIMPULAN}

Dari penelitian pembuatan penambahan fitur dari mesin laser engraver dan cutter, menunjukkan bahwa penambahan fitur dapat dibuat dengan baik dan sudah dicobakan pada tiga jenis file yang berbeda. Hasil dan kecepatan pengerjaaannya sama persis seperti yang dilakukan dengan menggunakan komputer atau PC biasa.

\section{UCAPAN TERIMA KASIH}

Ucapan terimakasih disampaikan kepada Kepala Laboratorium Robotika dan Kepala Laboratorium Pengemudian Listrik di Politeknik Elektronika Negeri Surabaya atas fasilitas laboratorium dan peralatannya.

\section{DAFTAR PUSTAKA/REFERENCES}

Anna Kaziunas France, Make: 3D Printing, Maker Media, 2014

Donald Noris, Programming with STM32: Getting Started with Nucleo board and C/C++, ISBN: 978-

\section{7}

Kirk Hausman, Richard Horne, 3D Printing for Dummies, John Wiley \& Sons, Inc., 2014

Moh. Dahlan, Budi Gunawan, F. Shoufika Hilyana,Rancang Bangun Printer 3D Menggunakan Kontroller Arduino Mega 2560, Jurusan Teknik Elektro, Fakultas Teknik, Universitas Muria Kudus, Prosiding SNATIF ke-4 Tahun 2017

Richard Salinas, 3D Printing with RepRap Cookbook, Packt Publishing, 2014

Warren Gay, Beginning STM32: Developing with FreeRTOS, libopencm3 and GCC, 2018, Apress, ISBN: 978-1484236246.

Hermawan, T., A. Syarief, M.H. Arisandi, M.D. Saptono, N. Destiana dan M. Atmomarsono. 2008. Viabilitas Streptococcus sp. Menggunakan Konsentrasi Gliserol yang Berbeda dalam TSB Selama Empat Bulan Preservasi Beku. Prosiding Hasil Uji Coba Preservarsi Vol 3. Pusat Karantina Ikan. Jakarta.

Joko T, Subandi A, Kusumandari N, Wibowo A, and Priyatmojo A. 2014. Activities of Plant Cell Walldegrading Enzymes by Bacterial Soft Rot Of Orchid. Arch. Phytopathol. Plant Prot. 47(10): 12391250. 
Miles, A. A. and Misra S. S. 1938. The Estimation of The Bactericidal Activity of Blood. Journal Of Hygiene 38:732-749.

Najmiyati, E. dan Dominikus A. H. 2012 Viabilitas Konsorsium Mikroba Pendegradasi Hidrokarbon Setelah Penyimpanan dalam Pendingin dan Penyimpanan Beku. Ecolab 6(2): 61-104.

Rakhashiya P.M., Patel P.P., Sheth B.P., Tank J.G., and Thaker V.S. 2016. Detection of Virulence and Pathogenicity Genes in Selected Phytopathovars. Arch. of Phytopathology Plant Protect. 49(1 - 4): 64-73.

Setiaji, J. 2015. Pengaruh Gliserol pada Media Tryptic Soy Broth (TSB) terhadap Viabilitas Bakteri Aeromonas hydrophila. Jurnal Dinamika Pertanian Vol.30(1):83-91.

Sudir. 2011. Pengaruh Varietas, Populasi Tanaman dan Waktu Pemberian Pupuk N terhadap Penyakit Padi. Prosiding Seminar Ilmiah Hasil Penelitian Padi Nasional 2010. Balai Besar Penelitian Tanaman Padi: 393-604.

Suparyono, Sudir, dan Suprihanto. 2004. Pathotype Profile of Xanthomonas campestris pv.oryzae, Isolates from The Rice Ecosystem in Java. Indonesian Jurnal of Agricultural Science 5(2): 63-69.

Wahyudi, A. T., S. Meliah, dan A. A. Nawangsih. 2011. Xanthomonas oryzae pv. oryzae Bakteri Penyebab Hawar Daun pada Padi: Isolasi, Karakterisasi, dan Telaah Mutagenesis dengan Transposon. Makara Sains 15(1): 89-96. 